\title{
Concentrations and uptake of micronutrients by oat and pea in intercrops in response to $\mathrm{N}$ fertilization and sowing ratio
}

\section{Konzentrationen und Aufnahme von Mikronährstoffen durch Hafer und Erbse in Gemengen in Abhängigkeit der N-Düngung und des Mischungsverhältnisses}

\author{
Reinhard W. Neugschwandtner ${ }^{1 *}$, Hans-Peter Kaul ${ }^{1}$
}

\begin{abstract}
${ }^{1}$ BOKU - University of Natural Resources and Life Sciences, Vienna, Department of Crop Sciences, Division of Agronomy, Konrad Lorenz-Str. 24, 3430 Tulln, Austria

*Corresponding author: reinhard.neugschwandtner@boku.ac.at
\end{abstract}

Received: 10 January 2016, accepted: 18 January 2016

\section{Summary}

Intercropping is of increasing interest in temperate regions. This study assessed the influence of nitrogen (N) fertilization and sowing ratio on concentrations and uptake of micronutrients copper $(\mathrm{Cu})$, iron $(\mathrm{Fe})$, manganese $(\mathrm{Mn})$, and zinc $(\mathrm{Zn})$ in grain and residue of oat and pea in three substitutive intercrops on a fertile soil in eastern Austria. $\mathrm{N}$ increased grain concentrations of $\mathrm{Cu}$ and $\mathrm{Zn}$ in oat and pea but decreased the nutrient harvest indices especially for pea. Intercropping did not affect grain concentrations of oat but those of pea were increased in one year in intercrops with a lower pea share. Residue concentrations of $\mathrm{Cu}$ and $\mathrm{Zn}$ in oat were increased in intercrops with lower oat share. Pea residue concentrations of all four micronutrients were affected by intercropping. Slightly higher grain nutrient yields could be obtained for $\mathrm{Mn}$ and $\mathrm{Zn}$ in oat-dominated unfertilized intercrops, whereas the residue micronutrient yields were higher in all intercrops compared to pure stands because of generally higher nutrient concentrations in intercrops. Consequently, advantages of oat-pea intercrops for increasing micronutrient yield in grain were limited, but intercropping can be a strategy for increasing the micronutrient yield in residue that can be used for ruminant feeding.

Keywords: intercropping, oat, pea, micronutrients, nutrient yield

\section{Zusammenfassung}

Das Interesse am Anbau von Gemengen nimmt in gemäßigten Klimazonen zu. Im vorliegenden Versuch wurden der Einfluss von Stickstoff-Düngung (N) und dem Mischungsverhältnis auf die Konzentrationen und Aufnahme der Mikronährstoffe Kupfer (Cu), Eisen (Fe), Mangan (Mn) und Zinc (Zn) in das Korn und die Ernterückstände von Hafer und Erbse, die in drei substitutiven Gemengen auf einem fruchtbaren Ackerstandort im Osten Österreichs gesät wurden, untersucht. N-Düngung erhöhte die Kornkonzentration von $\mathrm{Cu}$ und $\mathrm{Zn}$ bei Hafer und Erbse, reduzierte jedoch die Nährstoff-Ernteindices, insbesondere bei Erbse.

Die Korn-Nährstoffkonzentrationen des Hafers wurden durch den Gemengeanbau nicht beeinflusst, während jene der Erbse in einem Jahr in den Gemengen mit geringerem werdendem Erbsenanteil zunahmen. Die Nährstoffkonzentrationen von $\mathrm{Cu}$ und $\mathrm{Zu}$ in den Ernterückstände nahmen beim Hafer in den Gemengen mit geringer werdendem Haferanteil zu; auch jene der Erbse wurden durch den Gemengeanbau beeinflusst. Geringfügig höhere Korn-Nährstofferträge konnten nur für $\mathrm{Mn}$ und $\mathrm{Zn}$ in den Hafer-dominierten, ungedüngten Gemengen erreicht werden, während die Nährstofferträge der Ernterückstände in allen Gemengen höher waren als in den Reinsaaten, aufgrund der generell höheren Nährstoffkonzentrationen der Ernterückstände in den Gemengen. Infolgedessen sind die Vorteile von Hafer-Erbse-Gemengen hinsichtlich höhere Kornnährstofferträge begrenzt, während der Gemengeanbau eine Strategie sein kann, um höhere Nährstoffgehalte in den Ernterückständen zu erzielen, die für die Fütterung von Wiederkäuern eingesetzt werden können.

Schlagworte: Gemengeanbau, Hafer, Erbse, Mikronährstoffe, Nährstoffertrag 


\section{Introduction}

In intercropping systems, two or more crops are cultivated in such a way that they interact agronomically (Vandermeer, 1989). Benefits of intercropping are widely reported for grain yield and grain $\mathrm{N}$ yield. In pea-barley intercrop experiments conducted across Europe, grain $\mathrm{N}$ yield advantages of $25-30 \%$ were found compared to the respective sole crops (Hauggaard-Nielsen et al., 2009). In oat-pea intercrops grown in eastern Austria, no grain yield advantage was noticeable but a grain $\mathrm{N}$ yield advantage in unfertilized treatments could be observed because of the higher grain $\mathrm{N}$ concentrations of oat in intercrops (Neugschwandtner and Kaul, 2014, 2015). Oat-pea intercropping resulted in higher grain nutrient yields of macronutrients potassium $(\mathrm{K})$, magnesium $(\mathrm{Mg})$, and phosphorus $(\mathrm{P})$ in $\mathrm{N}$-unfertilized treatments and in higher residue macronutrients yields of calcium, $\mathrm{K}, \mathrm{Mg}$, and $\mathrm{P}$ over several $\mathrm{N}$ treatments compared to oat and pea pure stands (Neugschwandtner and Kaul, 2016).

Little consideration has been paid yet to micronutrient status of plants in intercrops, although intercropping could be an effective and a sustainable pathway for biofortification (of Fe and Zn) (Zuo and Zhang, 2009). Biofortification is the process of enriching nutrient concentrations of crops during growth (Jeong and Guerinot, 2008). Approaches for increasing micronutrient concentrations in food range from plant breeding to agronomic measures, for example, organic or inorganic fertilization, cultivar selection, or crop rotation (Rengel et al., 1999; Cakmak, 2008). Additionally, intercropping could facilitate micronutrient management because of the soil-plant-microbial interactions in the rhizosphere, which influence micronutrient availability (Watson et al., 2012). In multispecies ecosystems, the use of a resource (e.g., a nutrient) by plants may be characterized either by competition (for the same resource pool), complementarity (resource partitioning between intercrops through a differentiated use in time, space, and forms) (Fridley, 2001), or facilitation (one plant enhances the survival, resource availability, growth, or fitness of the other) (Callaway, 1995). For example, in wheat-chickpea intercrops, N, P, K, and Fe concentrations in wheat grain and $\mathrm{Mn}$ and $\mathrm{Zn}$ concentrations in chickpea grain increased compared to pure stands (Gunes et al., 2007).

Crop mixtures are extensively grown in traditional agricultural systems of developing countries (Biabani, 2009), and yield advantages have been reported for low soil fertility or low $\mathrm{N}$ fertilizer input systems (Bedoussac and Justes, 2011; Neugschwandtner and Kaul, 2014, 2015). Consequently, the focus of intercropping research on small-scale resource-poor systems has caused a knowledge gap in regards to high-input intercrop systems, which detracts from their rapid spread (Midmore, 1993), although there is an increasing interest in temperate regions for developing sustainable farming systems (Aufhammer et al., 2004; Kübler et al., 2008; Zając et al., 2014).

Therefore, the aim of this study was to assess oat-pea intercrops grown on a fertile soil in temperate conditions of eastern Austria as affected by $\mathrm{N}$ fertilization and sowing ratio with focus on (a) micronutrient concentrations of grain and residue, (b) uptake of micronutrients in grain and residue, and (c) nutrient harvest indices of intercrops as compared to pure stands of both crops.

\section{Material and methods}

\subsection{Environmental conditions}

The experiment was carried out in Raasdorf ( $48^{\circ} 14^{\prime} \mathrm{N}$, $\left.16^{\circ} 33^{\prime} \mathrm{E}\right)$ on the experimental farm Groß-Enzersdorf of the BOKU University in the east of Vienna, Austria, on the edge of the Marchfeld plain, in 2010 and 2011. The soil is rich in calcareous sediments and is classified as a chernozem of alluvial origin ( $\mathrm{pH}_{\mathrm{CaCl}_{2}}$ of 7.6 , silty loam, soil organic carbon is 2.2-2.3\%). Mehlich 3 (Mehlich, 1984) extractable micronutrient concentrations in 2010 or 2011 were 3.05 and $2.92 \mathrm{mg} \cdot \mathrm{kg}^{-1}$ of copper $(\mathrm{Cu}), 31.4$ and $29.2 \mathrm{mg} \cdot \mathrm{kg}^{-1}$ of iron (Fe), 68.0 and $62.0 \mathrm{mg} \cdot \mathrm{kg}^{-1}$ of manganese (Mn), and 4.2 and $3.4 \mathrm{mg} \cdot \mathrm{kg}^{-1}$ of zinc $(\mathrm{Zn})$. The mean annual temperature is $10.6^{\circ} \mathrm{C}$, and the mean annual precipitation is $538 \mathrm{~mm}$ (1980-2009). Table 1 shows the long-term average of monthly temperature and precipitation (1980-2009) from March until July and the deviations during the 2010 and 2011 growing seasons.

The temperature was generally higher in 2011 than in 2010, except for July. Monthly precipitation in 2010 was above the average during the growing season from April until July, whereas the experimental year 2011 was comparatively dry (Table 1).

\subsection{Experimental treatments and measurements}

Pure stands of oat (Avena sativa L., cv. Effektiv) and pea (Pisum sativum L., cv. Lessna) were established with 350 (oat) and 80 (pea) germinable seeds per square meter, respectively. Oat-pea intercrops were sown in one passover with an Oyjard plot drill in replacement series ("substitutive design") with sowing ratios (\%) of 75:25, 50:50, and 25:75 at a depth of $4 \mathrm{~cm}$ on March 19, 2010, and 
March 14, 2011. In addition to an unfertilized control, the nitrogen fertilizer calcium ammonium nitrate (CAN, $27 \% \mathrm{~N})$ was applied at two fertilization levels $(0,6$, and $12 \mathrm{~g} \mathrm{~N} \cdot \mathrm{m}^{-2}$ ) in two equal splits, right after sowing and at the end of tillering of oat, on May 2, 2010, and May 5, 2011. The experiments were established in a randomized complete block design with three replications. Individual plots had an area of $15 \mathrm{~m}^{2}(10 \times 1.5 \mathrm{~m})$ and comprised 10 rows at $12.5 \mathrm{~cm}$ spacing. The preceding crops were winter barley (2010) or spring barley (2011). Seedbed preparation was done with a tine cultivator to a depth of $20 \mathrm{~cm}$. Soil mineral $\mathrm{N}$ in $0-0.9 \mathrm{~m}$ depth at sowing was 15.8 (March 24, 2010) or 16.8 (March 16, 2011) $\mathrm{g} \mathrm{N} \cdot \mathrm{m}^{-2}$. Mechanical hand weeding was performed throughout the experiment. Plants were sprayed against pests when necessary (with deltamethrin, $7.5 \mathrm{~g}$ a.i. $\mathrm{ha}^{-1}\left(\right.$ Decis $\left.^{\circledR}\right)$ ). Plants were harvested manually by cutting on the soil surface at full ripeness on $1.2 \mathrm{~m}^{2}$ per plot on July 21, 2010, and July 19, 2011. Samples were split up into grain and residue of different species and dried at $70^{\circ} \mathrm{C}$ for 3 days.

\subsection{Nutrient determination}

For the determination of micronutrients, subsamples of grain and residue were ground, dried $\left(80^{\circ} \mathrm{C}\right.$ for $\left.4 \mathrm{~h}\right)$, and digested in a tri-acid mixture $\left(\mathrm{HNO}_{3}: \mathrm{H}_{2} \mathrm{SO}_{4}: \mathrm{HClO}_{4}=\right.$ 20:2:1, v/v/v) on a hot plate (Jackson, 1958). Concentrations of $\mathrm{Cu}, \mathrm{Fe}, \mathrm{Mn}$, and $\mathrm{Zn}$ in the digests were measured using atomic absorption spectrometry (Varian SpektrAA 300, Vienna, Austria) (Beaty and Kerber, 1993).

Grain and residue nutrient yields were calculated by multiplying yields with nutrient concentrations, and from these, the nutrient harvest indices (NutrHI) were calculated. The land equivalent ratio for nutrient yields $\left(\mathrm{LER}_{\mathrm{Nutr}}\right)$, which indicates a possible nutrient yield advantage of intercrops, was calculated modified according to Mead and Wiley (1980) as follows:

$$
\mathrm{LER}_{\text {Nutr }}=\mathrm{NutrY}_{\text {Oic }} / \mathrm{NutrY}_{\mathrm{Ops}}+\mathrm{Nutr}_{\text {Pic }} / \mathrm{NutrY}_{\mathrm{Pps}}
$$

where NutrY $Y_{\text {Ops }}$ and Nutr $Y_{\mathrm{Pps}}$ are the crop nutrient yields for oat $(\mathrm{O})$ and pea $(\mathrm{P})$ grown in pure stands (ps) and $\mathrm{NutrY}_{\text {Oic }}$ and NutrY $Y_{\text {Pic }}$ are the yields of the crops grown in intercrops (ic). An $\mathrm{LER}_{\mathrm{Nurr}}>1$ shows a nutrient yield advantage of the intercropping system, whereas an $\mathrm{LER}_{\text {Nurr }}<1$ indicates a nutrient yield disadvantage. The $\mathrm{LER}_{\text {Nutr }}$ is the sum of the partial $\mathrm{LER}_{\mathrm{Nurr}}$ of the individual crops in the mixture. The partial $\mathrm{LER}_{\mathrm{Nurr}}$ indicates the relative competitive ability of individual crops regarding nutrient yields in mixtures.

\subsection{Statistics}

Statistical analyses were performed using SAS version 9.2 by applying analysis of variance (PROC GLM) with subsequent multiple comparisons of means. Means were separated by least significant differences (LSD), when the F-test-indicated factorial effects on the significance level of $p<0.05$. On the basis of results of analysis of variance, data are presented for $\mathrm{N}$ fertilization (main effect) and interactions of crop $\times$ year. Other interactions are described in the text.

\section{Results}

\subsection{Grain and straw yield}

The effects of $\mathrm{N}$ fertilization and sowing ratio on grain and straw yields of oat-pea intercrops are described in Neug-

Table 1. Long-term average monthly temperature and precipitation (1980-2009) and deviations during the 2010 and 2011 growing seasons Tabelle 1. Langjährige durchschnittliche monatliche Temperatur und durchschnittlicher monatlicher Niederschlag (1980-2009) und die Abweichungen in den Vegetationsperioden 2010 und 2011

\begin{tabular}{|c|c|c|c|c|c|c|}
\hline & \multicolumn{3}{|c|}{ Temperature $\left({ }^{\circ} \mathrm{C}\right)$} & \multicolumn{3}{|c|}{ Precipitation $(\mathrm{mm})$} \\
\hline & \multirow[t]{2}{*}{ Mean } & \multicolumn{2}{|c|}{ Deviations } & \multirow[t]{2}{*}{ Mean } & \multicolumn{2}{|c|}{ Deviations } \\
\hline & & 2010 & 2011 & & 2010 & 2011 \\
\hline March & 5.8 & 0.5 & 0.5 & 38.5 & -33.3 & -10.1 \\
\hline April & 10.7 & 0.2 & 2.6 & 35.3 & 23.1 & -2.8 \\
\hline May & 15.6 & -0.3 & 0.3 & 56.1 & 58.6 & -12.5 \\
\hline June & 18.5 & 0.7 & 1.7 & 72.3 & 11.4 & -8.0 \\
\hline July & 20.8 & 1.8 & -0.5 & 59.1 & 12.8 & -4.3 \\
\hline
\end{tabular}


schwandtner and Kaul (2014). Briefly, N fertilization significantly increased grain and straw yields of oat but had no effect on these parameters of pea. Oat was the dominant partner in the mixtures strongly outcompeting pea. Grain and straw yields of oat slightly decreased with decreasing share in the intercrops, whereas pea yields were strongly affected. For example, with a share of $50 \%$ in the mixtures, the grain yields of oat decreased by $27 \%$ (2010) or $22 \%$ (2011), whereas the pea grain yields decreased by $91 \%$ (2010) or $83 \%$ (2011) compared to the corresponding pure stands (Figure 1). The harvest indices of pea were impaired by $\mathrm{N}$ fertilization. Intercropping resulted in a decrease in the harvest indices of both crops (data not shown).

\subsection{Micronutrient concentrations in grain and straw}

$\mathrm{N}$ fertilization increased concentrations of $\mathrm{Cu}$ and $\mathrm{Zn}$ in grain and residues of oat and pea, whereas concentrations of $\mathrm{Mn}$ were not affected in any fraction. Fe increased with $\mathrm{N}$ fertilization in oat residues (Table 2).

Sowing ratio did not affect the concentrations of $\mathrm{Cu}, \mathrm{Fe}, \mathrm{Mn}$, and $\mathrm{Zn}$ in oat grain, the concentrations of $\mathrm{Cu}, \mathrm{Fe}$, and $\mathrm{Mn}$ were higher in 2010 than in 2011 (Figure $2 \mathrm{a}-\mathrm{d}$ ). In pea grain, the concentrations of $\mathrm{Cu}, \mathrm{Fe}, \mathrm{Mn}$, and $\mathrm{Zn}$ increased with a lower sowing ratio of pea in the intercrops in 2010, whereas in 2011, no differences occurred between sowing ratios with higher values in 2010 than in 2011 (except for Fe, which had a higher concentration in the pure stands in 2011; Figure 3a-d). Concentrations in residues of oat and pea were considerably higher in 2010 than in 2011. Oat residue concentrations increased with lower oat share in the intercrops for $\mathrm{Cu}$ and $\mathrm{Zn}$. No differences were observed between sowing ratios for $\mathrm{Fe}$ and $\mathrm{Mn}$. Pea residue concentrations were the highest in the intercrops with $50 \%(\mathrm{Cu}, \mathrm{Zn}, \mathrm{Mn})$ and $75 \%(\mathrm{Fe}, \mathrm{Mn})$ pea share in 2010. In 2011, concentrations of Fe and Mn increased with a lower share of pea with no differences between sowing ratios for $\mathrm{Cu}$ and $\mathrm{Zn}$ (Figures $2 \mathrm{e}-\mathrm{h}$ and $3 \mathrm{e}-\mathrm{h}$ ).

Table 2. Concentrations and uptake of micronutrients in grain and residue of oat and pea as well as nutrient harvest indices as affected by $\mathrm{N}$ fertilizer level (means over sowing ratios and years)

Tabelle 2. Konzentrationen und Aufnahme von Mikronährstoffen in das Korn und die Ernterückstände von Hafer und Erbse sowie die Nährstoff-Ernteindices, beeinflusst durch das N-Düngeniveau (Mittelwerte über die Mischungsverhältnisse und Jahre)

\begin{tabular}{|c|c|c|c|c|c|c|c|c|c|c|}
\hline \multirow{3}{*}{$\begin{array}{l}\text { Fertilization } \\
\left(\mathrm{g} \mathrm{N} \cdot \mathrm{m}^{-2}\right)\end{array}$} & \multicolumn{4}{|c|}{ Concentration $\left(\mathrm{mg} \cdot \mathrm{kg}^{-1}\right)$} & \multicolumn{4}{|c|}{ Uptake $\left(\mathrm{mg} \cdot \mathrm{m}^{-2}\right)$} & \multirow{2}{*}{\multicolumn{2}{|c|}{$\begin{array}{l}\text { Nutrient harvest index } \\
\text { (\%) }\end{array}$}} \\
\hline & \multicolumn{2}{|c|}{ Grain } & \multicolumn{2}{|c|}{ Residue } & \multicolumn{2}{|c|}{ Grain } & \multicolumn{2}{|c|}{ Residue } & & \\
\hline & Oat & Pea & Oat & Pea & Oat & Pea & Oat & Pea & Oat & Pea \\
\hline & \multicolumn{10}{|c|}{ Copper } \\
\hline 0 & $4.60^{c}$ & $7.64^{\mathrm{b}}$ & $2.11^{\mathrm{c}}$ & $5.08^{b}$ & $1.61^{\mathrm{b}}$ & $1.52^{\mathrm{a}}$ & $1.18^{c}$ & $1.06^{\mathrm{b}}$ & $58.6^{\mathrm{a}}$ & $59.5^{a}$ \\
\hline 6 & $4.92^{b}$ & $8.53^{\mathrm{a}}$ & $2.36^{\mathrm{b}}$ & $5.57^{b}$ & $2.09^{\mathrm{a}}$ & $1.65^{\mathrm{a}}$ & $1.54^{\mathrm{b}}$ & $1.27^{\mathrm{ab}}$ & $57.4^{a}$ & $57.6^{a}$ \\
\hline \multirow[t]{2}{*}{12} & $5.53^{\mathrm{a}}$ & $8.89^{\mathrm{a}}$ & $2.82^{\mathrm{a}}$ & $7.11^{\mathrm{a}}$ & $2.31^{\mathrm{a}}$ & $1.62^{\mathrm{a}}$ & $1.89^{\mathrm{a}}$ & $1.42^{\mathrm{a}}$ & $55.8^{\mathrm{a}}$ & $49.2^{\mathrm{b}}$ \\
\hline & \multicolumn{10}{|c|}{ Iron } \\
\hline 0 & $84.6^{a}$ & $47.1^{\mathrm{a}}$ & $43.4^{\mathrm{b}}$ & $196^{\mathrm{a}}$ & $29.8^{\mathrm{a}}$ & $8.8^{\mathrm{a}}$ & $23.8^{\mathrm{c}}$ & $39.4^{\mathrm{a}}$ & $55.4^{a}$ & $23.0^{\mathrm{a}}$ \\
\hline 6 & $75.7^{\mathrm{a}}$ & $47.1^{\mathrm{a}}$ & $50.8^{\mathrm{b}}$ & $224^{a}$ & $32.2^{\mathrm{a}}$ & $10.2^{\mathrm{a}}$ & $33.9^{\mathrm{b}}$ & $40.5^{\mathrm{a}}$ & $51.2^{\mathrm{b}}$ & $20.0^{\mathrm{ab}}$ \\
\hline \multirow[t]{2}{*}{12} & $84.0^{\mathrm{a}}$ & $46.8^{\mathrm{a}}$ & $59.9^{\mathrm{a}}$ & $177^{\mathrm{a}}$ & $35.7^{a}$ & $9.6^{\mathrm{a}}$ & $41.5^{\mathrm{a}}$ & $38.6^{a}$ & $49.5^{\mathrm{b}}$ & $18.5^{b}$ \\
\hline & \multicolumn{10}{|c|}{ Manganese } \\
\hline 0 & $43.8^{a}$ & $13.4^{\mathrm{a}}$ & $39.8^{\mathrm{a}}$ & $49.2^{\mathrm{a}}$ & $15.4^{b}$ & $2.66^{a}$ & $21.5^{\mathrm{b}}$ & $9.12^{\mathrm{a}}$ & $44.3^{\mathrm{a}}$ & $23.0^{\mathrm{a}}$ \\
\hline 6 & $42.4^{a}$ & $13.3^{\mathrm{a}}$ & $37.2^{\mathrm{a}}$ & $51.0^{\mathrm{a}}$ & $17.4^{a}$ & $2.58^{\mathrm{a}}$ & $24.7^{b}$ & $9.48^{\mathrm{a}}$ & $44.3^{\mathrm{a}}$ & $20.8^{\mathrm{ab}}$ \\
\hline \multirow[t]{2}{*}{12} & $41.7^{\mathrm{a}}$ & $13.4^{a}$ & $41.4^{a}$ & $46.2^{a}$ & $17.9^{\mathrm{a}}$ & $2.62^{\mathrm{a}}$ & $28.4^{a}$ & $8.45^{\mathrm{a}}$ & $41.1^{\mathrm{b}}$ & $19.4^{\mathrm{b}}$ \\
\hline & \multicolumn{10}{|c|}{ Zinc } \\
\hline 0 & $23.3^{b}$ & $28.9^{\mathrm{b}}$ & $4.18^{\mathrm{b}}$ & $8.0^{\mathrm{b}}$ & $8.1^{\mathrm{b}}$ & $6.01^{\mathrm{a}}$ & $2.22^{\mathrm{b}}$ & $1.68^{b}$ & $78.9^{a}$ & $78.7^{a}$ \\
\hline 6 & $24.4^{b}$ & $33.9^{\mathrm{a}}$ & $4.42^{\mathrm{ab}}$ & $10.9^{\mathrm{a}}$ & $10.4^{a}$ & $6.65^{\mathrm{a}}$ & $2.95^{\mathrm{a}}$ & $2.21^{\mathrm{ab}}$ & $78.7^{\mathrm{a}}$ & $73.8^{b}$ \\
\hline 12 & $27.3^{\mathrm{a}}$ & $35.9^{\mathrm{a}}$ & $5.14^{\mathrm{a}}$ & $12.4^{\mathrm{a}}$ & $11.3^{\mathrm{a}}$ & $6.44^{a}$ & $3.41^{\mathrm{a}}$ & $2.23^{\mathrm{a}}$ & $77.1^{\mathrm{a}}$ & $69.7^{b}$ \\
\hline
\end{tabular}

Mean values followed by different letters are significantly different at $\mathrm{p}<0.05$. 

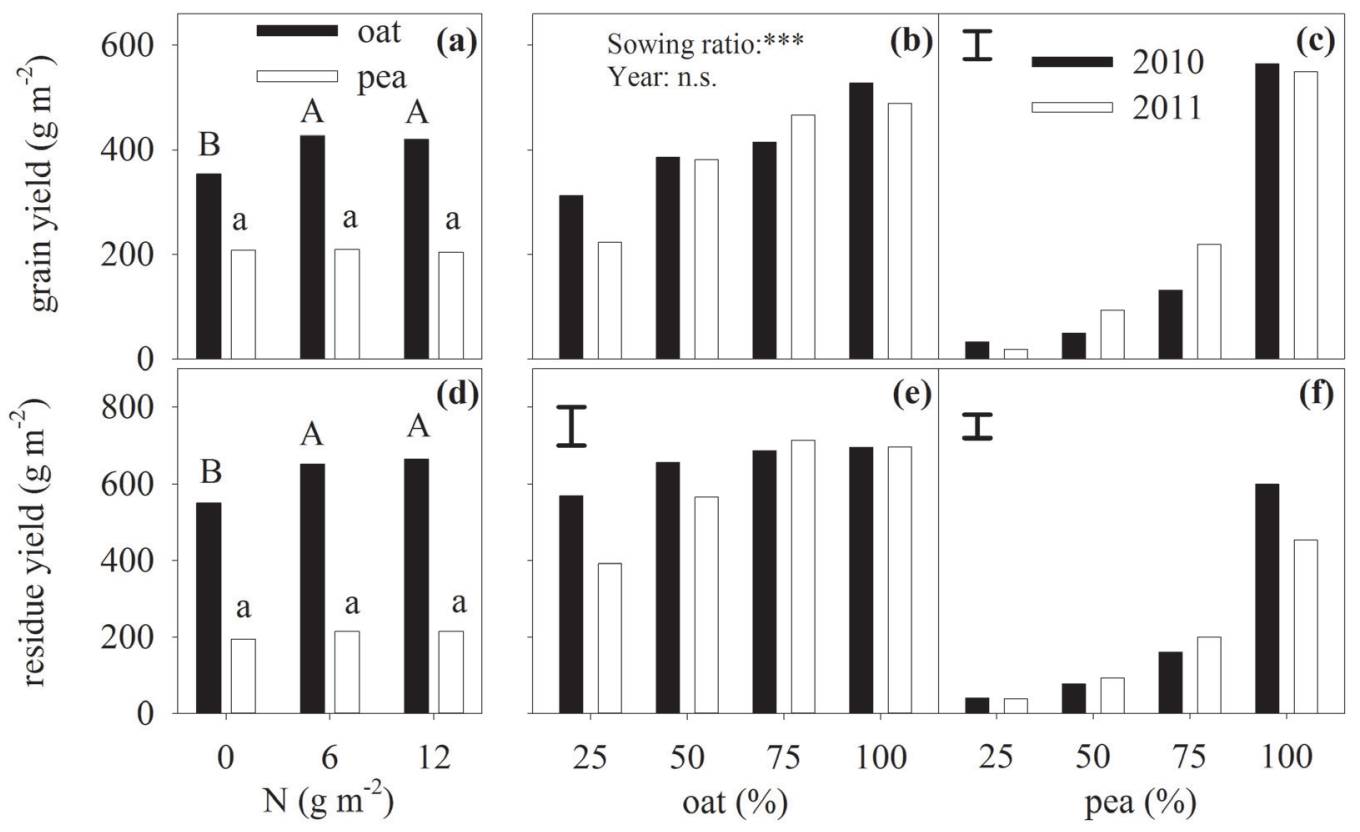

Figure 1. Grain $(\mathrm{a}, \mathrm{b}, \mathrm{c})$ and residue yield $(\mathrm{d}, \mathrm{e}, \mathrm{f})\left(\mathrm{g} \cdot \mathrm{m}^{-2}\right)$ of oat and pea depending on $\mathrm{N}$ fertilization (main effect) and sowing ratio $\times$ year (interaction). Different letters indicate significant differences, error bars are LSD $(\mathrm{p}<0.05)$. Asterisks indicate significant differences at $\mathrm{p}<0.001(* * *)$. Abbildung 1. Korn- (a, b, c) und Ernterückstandserträge (d, e, f) $\left(\mathrm{g} \cdot \mathrm{m}^{-2}\right)$ von Hafer und Erbse, beeinflusst von der N-Düngung (Hauptwirkung) und des Mischungsverhältnisses $\times$ Jahr (Wechselwirkung). Unterschiedliche Buchstaben zeigen signifikante Unterschiede, Fehlerbalken zeigen die Grenzdifferenz $(\mathrm{p}<0,05)$. Sternchen zeigen signifikante Unterschiede bei $\left.\mathrm{p}<0,001{ }^{* * *}\right)$.

\subsection{Uptake of micronutrients in grain and straw}

$\mathrm{N}$ fertilization increased uptake of $\mathrm{Cu}, \mathrm{Mn}$, and $\mathrm{Zn}$ in the grain of oat, while Fe uptake was not affected. In oat residue, uptake of all four analyzed micronutrients increased with $\mathrm{N}$ fertilization. Micronutrient uptake by pea grain was not affected by $\mathrm{N}$ fertilization. $\mathrm{Cu}$ and $\mathrm{Zn}$ increased with $\mathrm{N}$ fertilization in pea residue (Table 2).

Uptake of micronutrients by grain was the highest in the pure stands and decreased for both crops with a lower share on the sowing ratio. Grain uptake decline was much steeper for pea than for oat; for example, uptake by oat grain in intercrops with $25 \%$ oat share was $49 \%$ for $\mathrm{Cu}, 52 \%$ for $\mathrm{Fe}$, and $46 \%$ for $\mathrm{Mn}$ and $\mathrm{Zn}$ compared to the pure oat stands, whereas it was $5 \%$ for pea grain for $\mathrm{Cu}, \mathrm{Fe}, \mathrm{Mn}$, and $\mathrm{Zn}$, respectively, in intercrops with $25 \%$ pea compared to the pure pea stands (means across both years). Uptake by oat grain was generally higher in 2011 (Figures $2 \mathrm{i}-\mathrm{l}$ and $3 \mathrm{i}-\mathrm{l}$ ). Uptake of oat residues was about twofold higher for $\mathrm{Cu}$ and threefold higher for $\mathrm{Fe}, \mathrm{Mn}$, and $\mathrm{Zn}$ in $2010 \mathrm{com}$ pared to 2011. Residue uptake was higher in sowing ratios with an oat share of $75 \%$ for $\mathrm{Cu}$ and with a share of $75 \%$ and $50 \%$ for $\mathrm{Fe}$ than with $25 \%$ oat. No differences in oat residue uptake occurred for $\mathrm{Mn}$ and $\mathrm{Zn}$.

Uptake by pea residues was the highest in the pure pea stands and decreased with lower pea share in the intercrops, with a steeper decrease in 2010 than in 2011 (Figures $2 \mathrm{~m}-\mathrm{p}$ and $3 \mathrm{~m}-\mathrm{p}$ ).

A significant sowing ratio $\times$ fertilization interaction was observed for the uptake of $\mathrm{Cu}$ and $\mathrm{Zn}$ in grain and residue of pea. Uptake in grain increased with fertilization in the pea pure stands but was not affected in the intercrops with $75 \%$ pea share and decreased in intercrops with $50 \%$ and $25 \%$ pea. Uptake in residues increased with fertilization in the pure pea stands but was not affected in the intercrops (data not shown) (Table 2).

\subsection{Nutrient harvest index}

The NutrHI of oat decreased with $\mathrm{N}$ fertilization for Fe and $\mathrm{Mn}$. No effect was observed for $\mathrm{Cu}$ and $\mathrm{Zn}$. The NutrHI in pea was lower with $\mathrm{N}$ fertilization for all four analyzed micronutrients (Table 2). The NutrHI of oat was ranked as follows for sowing ratios of oat (in \%): $100>75,50>25$ for 
COPPER
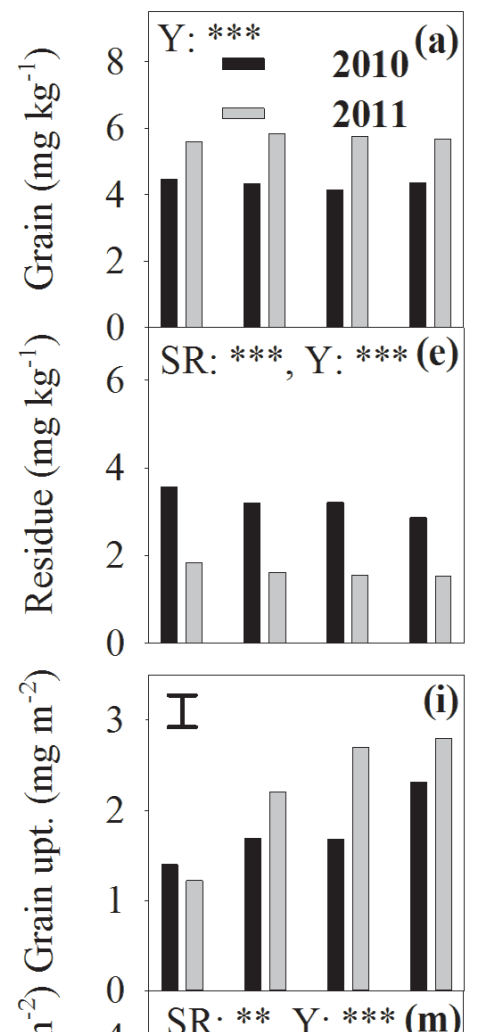

'ฆ 4 SR: **, Y:***(m)

吕 3

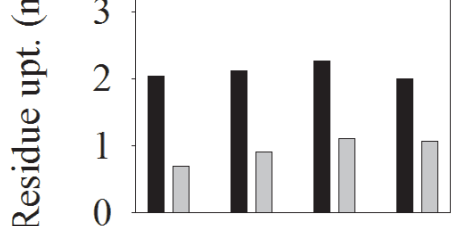

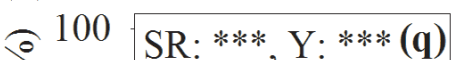

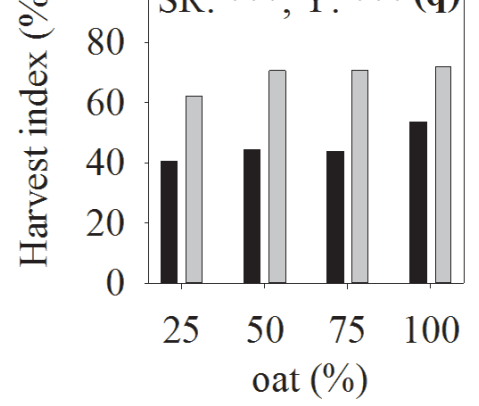

IRON

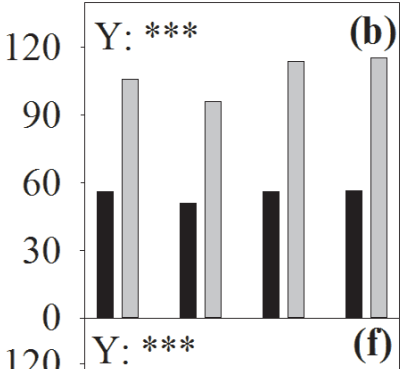

(f)

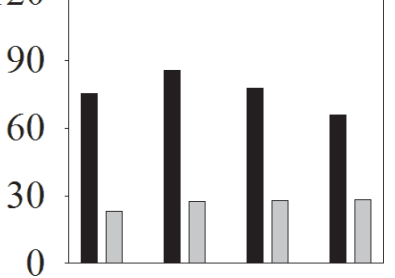

$60 \cdot \mathrm{I}$

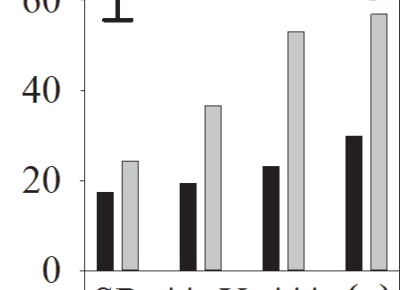

60 SR: **, Y: *** (n)

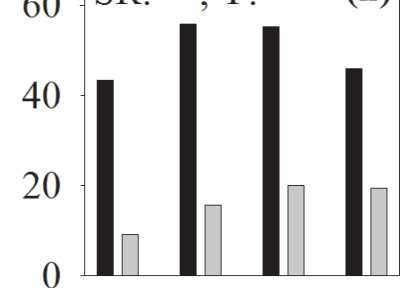

100

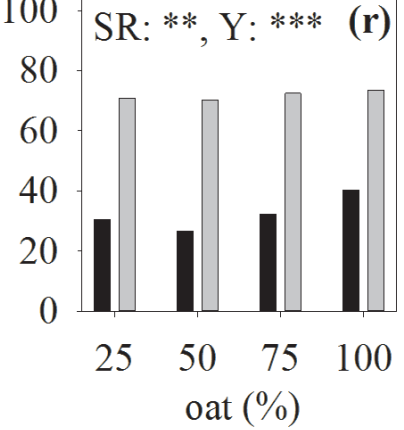

MAGNANESE

(c) 30
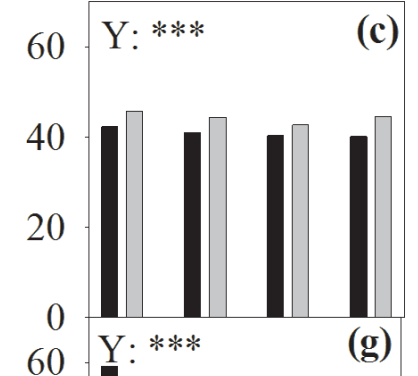

(g) 10
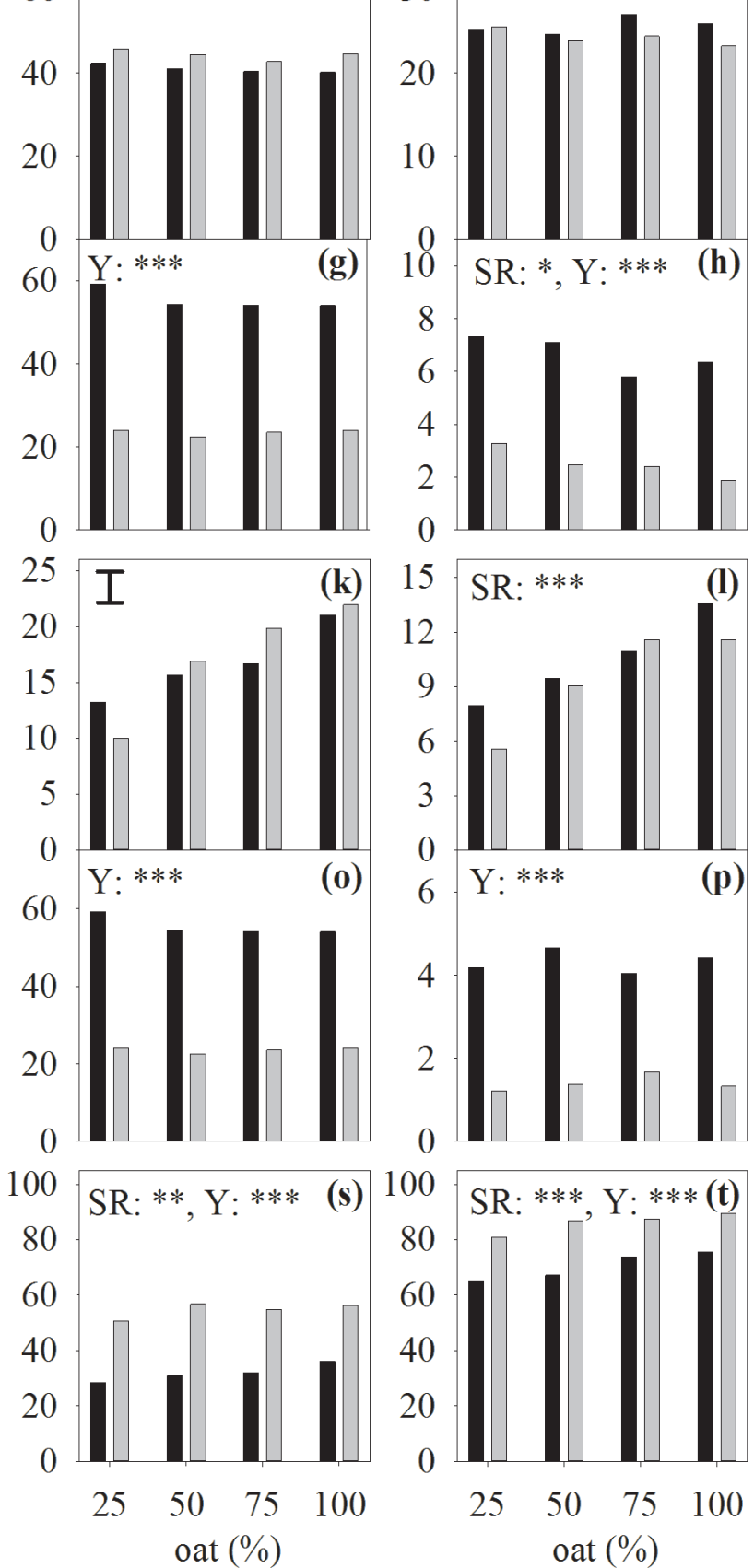

$0-\mathrm{SR}: *, \mathrm{Y}: * * *$

(h)
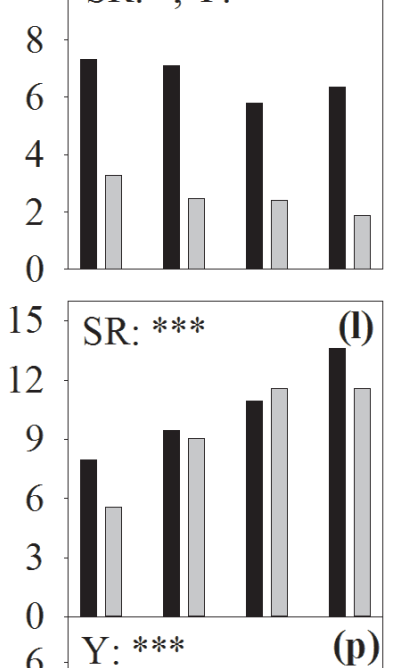

6. $\mathrm{Y}: * * *$

(p)

(d)

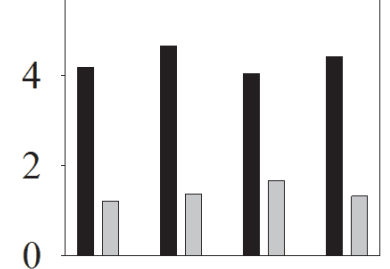

$00 \mathrm{SR}: * * *, \mathrm{Y}: * * *(\mathbf{t})$

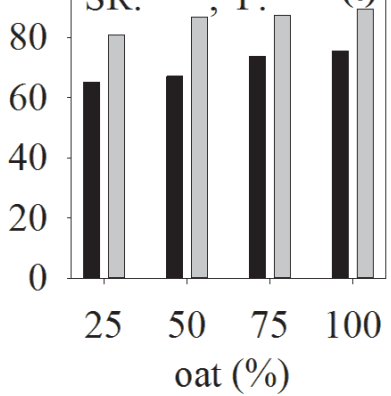

Figure 2. Grain $(\mathrm{a}-\mathrm{d})$ and residue $(\mathrm{e}-\mathrm{h})$ nutrient concentration, grain $(\mathrm{i}-\mathrm{l})$ and residue $(\mathrm{m}-\mathrm{p})$ uptake, and nutrient harvest index $(\mathrm{q}-\mathrm{t})$ of oat for copper, iron, manganese, and zinc depending on sowing ratio $(\mathrm{SR}) \times$ year $(\mathrm{Y})$ (interaction). Asterisks indicate significant differences at $\mathrm{p}<0.05\left({ }^{*}\right)$, $\mathrm{p}<0.01\left(^{(* *}\right)$, and $\mathrm{p}<0.001\left(^{* * *}\right)$. Error bars are LSD $(\mathrm{p}<0.05)$.

Abbildung 2. Nährstoffkonzentrationen im Korn (a-d) und den Ernterückständen (e-h), Aufnahme im Korn (i-l) und in den Ernterückständen $(\mathrm{m}-\mathrm{p})$ und Nährstoff-Ernteindices von Hafer für Kupfer, Eisen, Mangan und Zink, beeinflusst durch das Mischungsverhältnis $(\mathrm{SR}) \times \mathrm{Jahr}(\mathrm{Y})$ (Wechselwirkung). Sternchen zeigen signifikante Unterschiede bei $\mathrm{p}<0,05\left(^{*}\right), \mathrm{p}<0,01\left(^{* *}\right)$ und $\mathrm{p}<0,001\left({ }^{* * *}\right)$. Fehlerbalken zeigen die Grenzdifferenz $(\mathrm{p}<0,05)$. 


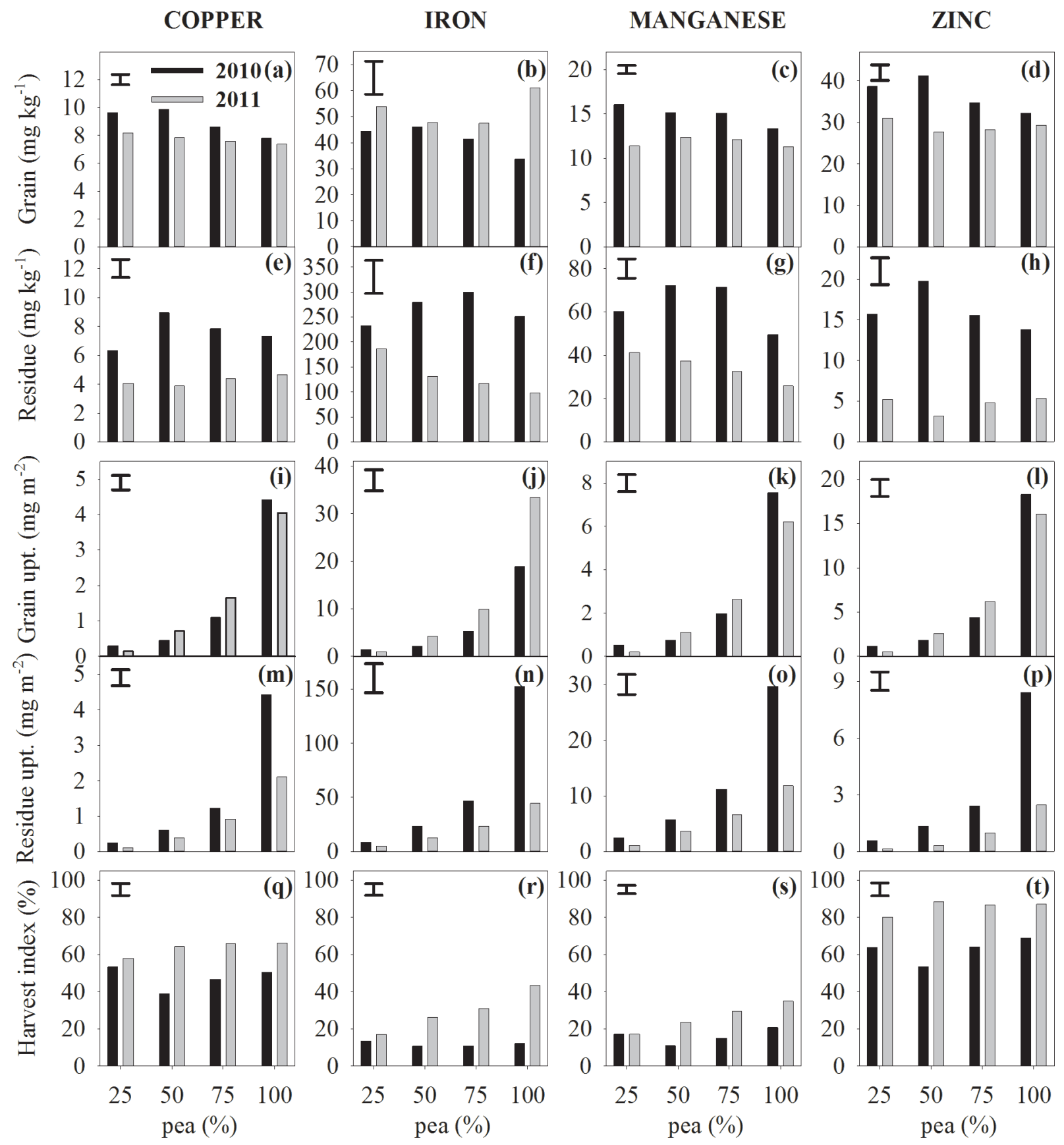

Figure 3. Grain $(\mathrm{a}-\mathrm{d})$ and residue $(\mathrm{e}-\mathrm{h})$ nutrient concentration, grain $(\mathrm{i}-\mathrm{l})$ and residue $(\mathrm{m}-\mathrm{p})$ uptake, and nutrient $(\mathrm{q}-\mathrm{t})$ harvest index of pea for copper, iron, manganese, and zinc depending on sowing ratio $(\mathrm{SR}) \times$ year $(\mathrm{Y})$ (interaction). Error bars are LSD $(\mathrm{p}<0.05)$.

Abbildung 3. Nährstoffkonzentrationen im Korn (a-d) und den Ernterückständen (e-h), Aufnahme im Korn (i-l) und in den Ernterückständen $(\mathrm{m}-\mathrm{p})$ und Nährstoff-Ernteindices von Erbse für Kupfer, Eisen, Mangan und Zink, beeinflusst durch das Mischungsverhältnis $(\mathrm{SR}) \times \mathrm{Jahr}(\mathrm{Y})$ (Wechselwirkung). Fehlerbalken zeigen die Grenzdifferenz $(\mathrm{p}<0,05)$. 


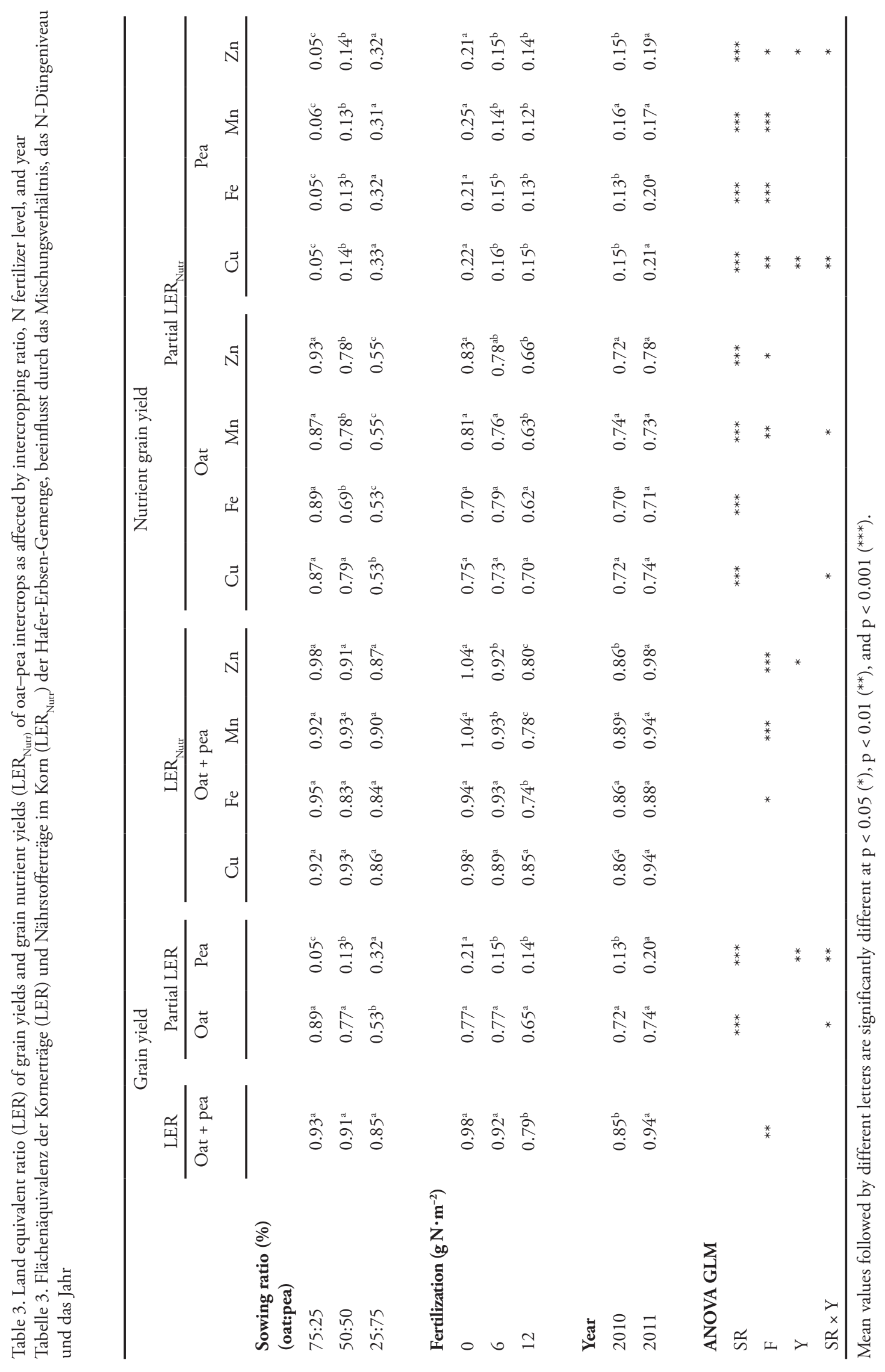




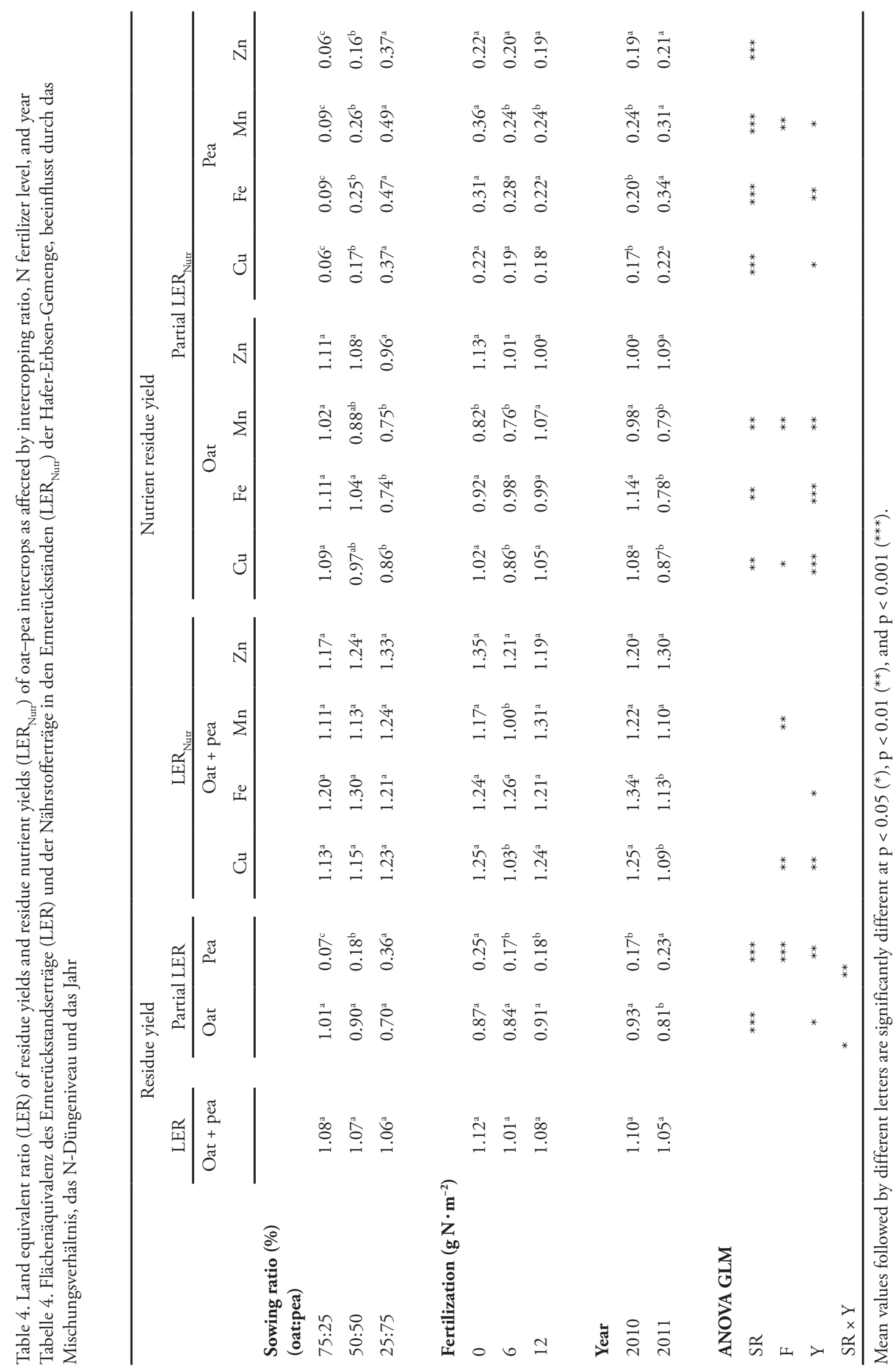


$\mathrm{Cu} ; 100 \geq 75 \geq 50,25$ for Fe; $100,75,50>25$ for $\mathrm{Mn}$; and $100 \geq 75 \geq 50>25$ for $\mathrm{Zn}$ (Figure 2q-t). The NutrHI of pea was the lowest for $\mathrm{Cu}$ and $\mathrm{Zn}$ with $50 \%$ pea in 2010 and 25\% pea in 2011; the NutrHI of pea decreased for Fe and Mn with lower pea shares in 2011, whereas no differences between sowing ratios were observed in 2010 (Figure 3q-t).

\subsection{Land Equivalent Ratio for nutrient yields $\left(\mathrm{LER}_{\mathrm{Nutr}}\right)$}

The grain and residue LER and the partial grain LER were already described in Neugschwandtner and Kaul (2014; also shown in Table 3). Briefly, the total grain LERs were below unity (indicating a lower grain productivity of the intercrops) and decreased with fertilization, whereas the total residue LERs were above unity (indicating a higher residue productivity of the intercrops) and unaffected by fertilization (Table 4). Fertilization did not affect the partial grain and residue LERs of oat, whereas those of pea decreased with $\mathrm{N}$ fertilization. The partial grain and residue LERs were considerably higher for oat than for pea, highlighting that oat was the dominant crop in the mixtures. The partial grain and residue LERs decreased for both crops with a lower share in the intercrops (with a steeper decrease in 2011 than in 2010) (data not shown).

The values for total grain $\mathrm{LER}_{\text {Nutr }}$ were generally in a similar range as the total grain LER, whereas the values for total residue $L_{E R} R_{\text {Nutr }}$ were generally higher than the total residue LERs (Tables 3 and 4).

Fertilization impaired total grain nutrient $\mathrm{LER}_{\text {Nutr }}$ for analyzed micronutrients (not significant for $\mathrm{Cu}$ ). In unfertilized treatments, values $>1$ occurred for $\mathrm{Mn}$ and $\mathrm{Zn}$. The total grain LER $_{\text {Nutr }}$ for Zn was lower in 2010 than in 2011. The total grain $\mathrm{LER}_{\mathrm{Nutr}}$ was generally the highest in the intercrops with $75 \%$ oat and $25 \%$ pea share (not significant). The total grain $\mathrm{LER}_{\text {Nutr }}$ was clearly above unity for $\mathrm{Mn}$ and $\mathrm{Zn}$ in unfertilized 75\%:25\% and 50\%:50\% oat-pea intercrops (except for $\mathrm{Mn}$ in the 75\%:25\% intercrops in 2010) (data not shown). The partial grain $\operatorname{LER}_{\text {Nutr }}$ was the highest for both crops with their highest share in the intercrops with values around 0.9 for oat in the intercrops with $75 \%$ oat, whereas pea in the intercrops with $75 \%$ pea share achieved a partial grain $\mathrm{LER}_{\mathrm{Nutr}}$ of around one-third and with a share of $25 \%$ pea just values of $0.05-0.06$. Fertilization impaired the partial grain $\mathrm{LER}_{\mathrm{Nutr}}$ of oat for $\mathrm{Mn}$ and $\mathrm{Zn}$ and that of pea for all analyzed micronutrients (Table 3). There was a significant sowing ratio $x$ year interaction for the partial grain $\mathrm{LER}_{\mathrm{Nutr}}$ of oat for $\mathrm{Cu}$ and $\mathrm{Mn}$ and pea for $\mathrm{Cu}$ and $\mathrm{Zn}$ : the uptake decreased for each crop with a lower share of the crop in the intercrops, but in 2011, the decline was steeper than in 2010 (data not shown).

The total residue $\mathrm{LER}_{\text {Nutr }}$ was clearly $>1$ with no differences between intercrops. The total residue LER $_{\text {Nutr }}$ was the lowest with $6 \mathrm{~g} \mathrm{~N} \cdot \mathrm{m}^{-2}$ for $\mathrm{Cu}$ and $\mathrm{Mn}$ and for $\mathrm{Cu}$ and Fe in 2011 compared to 2010. The partial residue LER $_{\text {Nurr }}$ of oat was $>1$ for $\mathrm{Cu}, \mathrm{Fe}, \mathrm{Mn}$, and $\mathrm{Zn}$ in intercrops with $75 \%$ oat and $>1$ for $\mathrm{Fe}$ and $\mathrm{Zn}$ in intercrops with $50 \%$ oat. It decreased in intercrops with $25 \%$ oat share just to values between $0.74(\mathrm{Fe})$ and $0.96(\mathrm{Zn})$. Fertilization with $6 \mathrm{~g} \mathrm{~N} \cdot \mathrm{m}^{-2}$ impaired the partial residue $\mathrm{LER}_{\text {Nutr }}$ of oat for $\mathrm{Cu}$ and $\mathrm{Mn}$. The partial residue $\mathrm{LER}_{\mathrm{Nutr}}$ of oat was lower in 2011 than in 2010 for $\mathrm{Cu}, \mathrm{Fe}$, and $\mathrm{Mn}$. The partial residue $\operatorname{LER}_{\text {Nurr }}$ of pea in intercrops with $75 \%$ pea share was $0.37(\mathrm{Cu}$ and $\mathrm{Zn}), 0.47(\mathrm{Fe})$, and $0.49(\mathrm{Mn})$. In intercrops with $25 \%$ pea share, it was below 0.1 for all four micronutrients. Fertilization decreased the partial residue LER $_{\text {Nutr }}$ of pea just for $\mathrm{Mn}$. The partial residue $\mathrm{LER}_{\mathrm{Nutr}}$ of pea was lower in 2010 than in 2011 for $\mathrm{Cu}, \mathrm{Fe}$, and Mn (Table 4).

\section{Discussion}

Micronutrient concentrations in grain and residue varied between the cooler and wetter year 2010 and the drier and hotter year 2011. Nutrient concentrations and nutrient uptake in crops are reported to be reduced by drought because of its effects on root growth, lower nutrient mobility in the soil, and reduced transpiration flow (Fageria et al., 2002; Gunes et al., 2006). Accordingly, concentrations of all four analyzed micronutrients in the residue of both crops and $\mathrm{Cu}, \mathrm{Mn}$, and $\mathrm{Zn}$ in pea grain were generally considerably higher in 2010 than in 2011. Contrary to that, $\mathrm{Cu}, \mathrm{Fe}$, and $\mathrm{Mn}$ were lower in oat grain in 2010 than in 2011. Also Neugschwandtner et al. (2015a) have reported higher concentrations of $\mathrm{Cu}$ and $\mathrm{Zn}$ in grain and residue of pea under conditions of drought.

Diverse results have been reported for the influence of $\mathrm{N}$ fertilization on micronutrient concentrations. Similar to our results with higher $\mathrm{Cu}$ and $\mathrm{Zn}$ concentrations (and no alterations of $\mathrm{Fe}$ and $\mathrm{Mg}$ ) in grain of oat and pea with $\mathrm{N}$ fertilization, Shi et al. (2010) reported higher concentrations of $\mathrm{Cu}, \mathrm{Fe}$, and $\mathrm{Zn}$ (but not of $\mathrm{Mn}$ ) with $\mathrm{N}$ fertilization for wheat. They further observed that the proportions of elements were different between milling fractions attributing this to different pathways for the translocation and accumulation of individual micronutrients to the grain that are 
influenced by N. Also Ciampitti and Vyn (2013) reported higher $\mathrm{Cu}, \mathrm{Fe}$, and $\mathrm{Mn}$ concentrations with $\mathrm{N}$ fertilization for maize grain in pure stands. Contrary to that, no effect of $\mathrm{N}$ fertilization on concentrations of $\mathrm{Fe}$ and $\mathrm{Zn}$ in grain of winter wheat and spring barley was observed by Sedlár et al. (2014) and on micronutrient concentrations in grain of maize by Lošák et al. (2011). Ahmadi et al. (1993) observed even lower concentrations of $\mathrm{Cu}, \mathrm{Zn}$, and $\mathrm{Mn}$ with $\mathrm{N}$ fertilization in oat grain, attributing this to a dilution because of a higher grain yield.

Nutrient concentrations in pea were more affected by intercropping compared to oat. Oat grain had similar concentrations in all treatments, whereas pea grain had higher micronutrient concentrations in intercrops with a lower pea share in one year. Concentrations in residues were higher for $\mathrm{Cu}$ and $\mathrm{Fe}$ with lower oat shares but for all four elements in pea residues in some intercrops. Micronutrient concentrations of legumes in grass-legume mixtures grown in Denmark with different $\mathrm{N}$ regimes were found to be relatively constant between pure stands and mixtures but the concentrations in grasses were increased (Høgh-Jensen and Søegaard, 2012). A reason for differences in nutrient concentrations because of different plant densities (in which each component species in the substitutive intercrops occurred) can be concentration or dilution processes. For example, the grain $\mathrm{N}$ concentrations in pure wheat stands with higher seeding rate can be lower (at higher thousand-kernel weight (TKW)) (Arduini et al., 2006) or higher (at lower TKW) (Dai et al., 2013), whereas no influence of plant density was reported for $\mathrm{Cu}$, $\mathrm{Fe}, \mathrm{Mn}$, and $\mathrm{Zn}$ in grain of maize pure stands (Ciampitti and Vyn, 2013). Further on, facilitation mechanisms between gramineous species and dicots for the uptake of nutrients have been reported by Zhang et al. (2010) (for Fe and $\mathrm{Zn}$ ). For example, the release of root exudes (citric acid) in the rhizosphere of white lupin in an alkaline soil caused acidification and subsequent release of $\mathrm{P}$ as well as $\mathrm{Cu}, \mathrm{Fe}, \mathrm{Mn}$, and $\mathrm{Zn}$ (Gardner et al., 1983; Dinkelaker et al., 1989). Consequently, a facilitation of the mineral nutrition of wheat and chickpea in intercrops has been reported with higher grain concentrations of $\mathrm{N}, \mathrm{P}, \mathrm{K}$, and $\mathrm{Fe}$ in wheat and $\mathrm{Mn}$ and $\mathrm{Zn}$ in chickpea and higher shoot concentrations of $\mathrm{P}, \mathrm{K}, \mathrm{Fe}, \mathrm{Mn}$, and $\mathrm{Zn}$ in wheat and $\mathrm{Mn}$ and $\mathrm{Zn}$ in chickpea (whereas $\mathrm{N}, \mathrm{P}$, and $\mathrm{K}$ decreased in chickpea shoots) (Gunes et al., 2007). The positive influence of accompanying plants has also been shown in strip intercropping experiments: a higher concentration of $\mathrm{Cu}$ and $\mathrm{Fe}$ was observed for maize biomass placed next to bean compared to maize in the centre of the strip that was more distant to bean (but for which a higher Mn concentration was reported) (Głowacka, 2013). Similar to our results, Li et al. (2004) observed in wheat-chickpea intercrops higher $\mathrm{Zn}$ concentrations in the shoots of both the crops and higher Mn concentrations in the shoots of chickpea.

Differing results have been reported for Fe concentrations in cereal-legume intercrops. Our results showed just effects on pea grain and residue in one year. An enhancement of $\mathrm{Fe}$ concentrations has also been observed for peanut leaves intercropped with maize (Zuo et al., 2000), maize intercropped with bean (Głowacka, 2013), and for both species in wheat-chickpea intercrops (Gunes et al., 2007). In an Fe-deficient calcareous sandy soil, $\mathrm{Cu}, \mathrm{Fe}$, and $\mathrm{Zn}$ concentrations and chlorophyll content of peanut shoots intercropped with gramineous species (barley, oat, maize, or wheat) were much higher than those in monocropped peanut (Zuo and Zhang, 2008). Two reasons are given for that observation: dicot plants such as peanut and pea increase reductase activity under Fe deficiency and the release of protons and reductants is enhanced from the roots to mobilize Fe from the rhizosphere (Schmidt, 2003; Zuo and Zhang, 2008). On the other hand, gramineous plants exudate phytosiderophores into the rhizosphere under $\mathrm{Fe}$ and $\mathrm{Zn}$ deficiency to increase the availability of Fe and Zn (Marschner et al., 1998; Schmidt, 2003). The release of phytosiderophores by maize was also found to increase the $\mathrm{Zn}$ nutrition of an accompanying peanut crop (Inal et al., 2007). For Fe and Mn, there are antagonistic reactions in the uptake of these elements in plants (Tanaka and Navasero, 1966). Consequently, higher Fe but lower $\mathrm{Mn}$ concentrations have been observed in intercrops for maize strip cropped with bean (Głowacka, 2013), whereas in maize-peanut intercrops, the shoot concentrations of Fe were increased in peanut but $\mathrm{Mn}$ in peanut shoots and $\mathrm{Fe}$ and $\mathrm{Mn}$ in maize shoots were not affected (Inal et al., 2007). We observed no changes for $\mathrm{Mn}$ in grain and residue of oat but higher values in intercropped pea in one year for both Fe and Mn. Lošák et al. (2011) also stated that $\mathrm{Fe}$ did not inhibit the uptake of $\mathrm{Mn}$ in maize grain. Uptake of $\mathrm{Cu}, \mathrm{Mn}$, and $\mathrm{Zn}$ in grain and $\mathrm{Cu}, \mathrm{Fe}, \mathrm{Mn}$, and $\mathrm{Zn}$ in residue of oat increased with $\mathrm{N}$ fertilization through both higher concentrations of these elements and a higher biomass production with $\mathrm{N}$ fertilization. While no higher uptake with $\mathrm{N}$ fertilization was observed for pea grain, the higher uptake of $\mathrm{Cu}$ and $\mathrm{Zn}$ in pea residues was caused by higher element concentrations with $\mathrm{N}$ fertilization. Lower 
nutrient harvest indices of oat for $\mathrm{Fe}$ and $\mathrm{Mn}$ and of pea for $\mathrm{Cu}, \mathrm{Fe}, \mathrm{Mn}$, and $\mathrm{Zn}$ indicate that nutrient uptake efficiency was more enhanced than nutrient utilization efficiency with $\mathrm{N}$ fertilization (cf. Neugschwandtner et al., 2015b). Crop-specific uptake of micronutrients by grain and residue of oat and pea decreased with lower share for each crop with a lower decrease for the dominant crop oat than for pea.

The total grain $\operatorname{LER}_{\text {Nutr }}$ was clearly above unity only for $\mathrm{Mn}$ and $\mathrm{Zn}$ in unfertilized 75\%:25\% and 50\%:50\% oatpea intercrops (except for $\mathrm{Mn}$ in the 75\%:25\% intercrop in 2010). Consequently, a grain nutrient yield advantage by intercropping oat and pea could just be obtained in these intercrops compared to pure oat and pea stands. On the other side, the total residue $\mathrm{LER}_{\text {Nutr }}$ was partly considerably above unity, indicating a high nutrient yield advantage in residue of oat-pea intercrops at each sowing ratio compared to pure stands.

The contribution of oat to the total grain and residue $\mathrm{LER}_{\text {Nutr }}$ was considerably higher than that of pea as considerably higher partial $\mathrm{LER}_{\text {Nutr }}$ of oat than of pea at equal sowing ratios of each crop show. Values of the total grain LER $_{\text {Nutr }}$ were generally in a similar range as the total grain LER as just the grain concentrations of pea (which was not as strongly represented as oat in the intercrops) were partly increased in the intercrops. The total residue LERNurr, however, was generally higher than the total residue LER as for both crops statistically confirmed or at least tendencies of higher nutrient concentrations in intercrops were observed.

The nutrient harvest index especially of oat and partly of pea decreased with a lower share of the crops in the intercrops, indicating that the nutrient utilization efficiency was lower in intercrops than in pure stands.

Micronutrients (including $\mathrm{Cu}, \mathrm{Fe}, \mathrm{Mn}$, and $\mathrm{Zn}$ ) are required for ruminant feeding especially as central elements of enzymes. Deficiencies can negatively affect growth and fertility (Hidiroglou 1979; Fischer, 2008). Ideally, mineral nutrition requirements of livestock should be covered by a judicious combination of natural feeds (e.g., by adding protein concentrates to a grain mixture). Additionally, mineral supplements are used to meet requirements (Suttle, 2010). For example, supplementation of dairy cow diets with $\mathrm{Cu}$, $\mathrm{Mn}, \mathrm{Zn}$, and cobalt reduced days to first estrus (Campbell et al., 1999) and increased milk production (Yamamoto et al., 2014). The body weight gain of crossbred male calves was shown to increase with the supplementation of $\mathrm{Cu}, \mathrm{Fe}$, Mn, and Zn (Mondal et al., 2009).
Micek et al. (2012) have reported that intercropping resulted in a higher protein yield and a higher nutritive value of harvested grains for food and feed. Additionally, crop residues are an important feed resource for ruminants (especially in developing countries) (Zerbini and Thomas, 2003). Feeding residues may constitute a major part of the maintenance ration for wintering mature, dry, pregnant beef cows but is not recommended for feedlot cattle (Anderson, 1978). However, residues are often severely deficient in one or more major nutrients required by ruminants (including protein, vitamins, and minerals) (Coleman and Moore, 2003), and detailed nutritional analysis of residues is often not available (McCartney et al., 2006). Consequently, quality-improved residues could help to meet additional feed demands of ruminants, which arise owing to the increasing demand for livestock products (Bartle and Klopfenstein, 1988).

\section{Conclusion}

In oat-pea intercrops grown on a fertile soil in eastern Austria, higher micronutrient grain yields could just be obtained for $\mathrm{Mn}$ and $\mathrm{Zn}$ in unfertilized intercrops with a medium to high oat share, whereas the micronutrient residue yields of the intercrops surpassed those of the pure stands of both crops. This indicates that possible benefits for obtaining higher micronutrient yields with intercrops for producing grain feed are limited to a low $\mathrm{N}$ input level, whereas higher micronutrient residue yields are achievable over all intercropping ratios and fertilization levels. Thus, intercropping can be a strategy for increasing micronutrient yield in residue that can be used for ruminant feeding.

\section{References}

Ahmadi, M., Beuerlein, J.E., Wiebold, W.J. and J.H. Cline (1993): Effects of cultural practices on oat grain yield and mineral composition. Communications in Soil Science and Plant Analysis 24, 457-474.

Anderson, D.C. (1978): Use of cereal residues in beef cattle production systems. Journal of Animal Science 46, 849-861.

Arduini, I., Masoni, A., Ercoli, L. and M. Mariotti (2006): Grain yield, and dry matter and nitrogen accumulation and remobilization in durum wheat as affected by va- 
riety and seeding rate. European Journal of Agronomy 25, 309-318.

Aufhammer, W., Kübler, E. and H.-P. Piepho (2004): Cereals and grain legumes as components of mixed stands - $1^{\text {st }}$ communication: Mixing effects on grain yield. Pflanzenbauwissenschaften 8, 56-63.

Bartle, S.J. and T.J. Klopfenstein (1988): Nonchemical opportunities for improving crop residue feed quality: A review. Journal of Production Agriculture 1, 356-361.

Beaty, R.D. and J.D. Kerber (1993): Concepts, Instrumentation and Techniques in Atomic Absorption Spectrophotometry. $2^{\text {nd }}$ ed., The Perkin-Elmer Corporation, Norwalk, CT, USA.

Bedoussac, L. and E. Justes (2011): A comparison of commonly used indices for evaluating species interactions and intercrop efficiency: Application to durum wheatwinter pea intercrops. Field Crop Research 124, 25-36.

Biabani, A. (2009): Agronomic performance of intercropped wheat cultivars. Asian Journal of Plant Sciences 8, 78-81.

Cakmak, I. (2008): Enrichment of cereal grains with zinc: Agronomic or genetic biofortification? Plant and Soil 302, 1-17.

Callaway, R.M. (1995): Positive interactions among plants. Botanical Review 61, 306-349.

Campbell, M.H., Miller, J.K. and F.N. Schrick (1999): Effect of additional cobalt, copper, manganese, and zinc on reproduction and milk yield of lactating dairy cows receiving bovine somatotropin. Journal of Dairy Science 82, 1019-1025.

Ciampitti, I.A. and T.J. Vyn (2013): Maize nutrient accumulation and partitioning in response to plant density and nitrogen rate: II. Calcium, Magnesium, and Micronutrients. Agronomy Journal 105, 1645-1657.

Coleman, S.W. and J.E. Moore (2003): Feed quality and animal performance. Field Crops Research 84, 17-29.

Dai, X., Zhou, X., Jia, D., Xiao, L., Kong, H. and M. He (2013): Managing the seeding rate to improve nitrogen-use efficiency of winter wheat. Field Crops Research 154, 100-109.

Dinkelaker, B., Römheld, V. and H. Marschner (1989): Citric acid excretion and precipitation of calcium citrate in the rhizosphere of white lupin (Lupinus albus $\mathrm{L}$ ). Plant and Cell Physiology 12, 285-292.

Fageria, N.K., Baligar, V.C. and R.B. Clark (2002): Micronutrients in crop production. Advances in Agronomy 77, 185-268.

Fischer, G.E.J. (2008): Micronutrients and animal nutrition and the link between the application of micronu- trients to crops and animal health. Turkish Journal of Agriculture and Forestry 32, 221-233.

Fridley, J.D. (2001): The influence of species diversity on ecosystem productivity: How, where, and why? Oikos 93, 514-526.

Gardner, W.K., Barber, D.A. and D.G. Parbery (1983): The acquisition of phosphorus by Lupinus albus L. III. The probable mechanism by which phosphorus movement in the soil/root interface is enhanced. Plant and Soil 70, 107-124.

Głowacka, A. (2013): Uptake of $\mathrm{Cu}, \mathrm{Zn}, \mathrm{Fe}$ and $\mathrm{Mn}$ by maize in the strip cropping system. Plant, Soil and Environment 59, 322-328.

Gunes, A., Cicek, N., Inal, A., Alpaslan, M., Eraslan, F., Guneri, E. and T. Guzelordu (2006): Genotypic response of chickpea (Cicer arietinum L.) cultivars to drought stress implemented at pre- and post-anthesis stages and its relations with nutrient uptake and efficiency. Plant, Soil and Environment 52, 368-376.

Gunes, A., Inal, A., Adak, M.S., Alpaslan, M., Bagci, E.G., Erol, T. and D.J. Pilbeam (2007): Mineral nutrition of wheat, chickpea and lentil as affected by mixed cropping and soil moisture. Nutrient Cycling in Agroecosystems 78, 83-96.

Hauggaard-Nielsen, H., Gooding, M., Ambus, P., CorreHellou, G., Crozat, Y., Dahlmann, C., Dibet, A., von Fragstein, P., Pristeri, A., Monti, M. and E.S. Jensen (2009): Pea-barley intercropping and short-term subsequent crop effects across European organic cropping conditions. Nutrient Cycling in Agroecosystems 85, 141-155.

Hidiroglou, M. (1979): Trace element deficiencies and fertility in ruminants: A review. Journal of Dairy Science 62, 1995-2206.

Høgh-Jensen, H. and K. Søegaard (2012): Robustness in the mineral supply from temporary grasslands. Acta Agriculturae Scandinavica, Section B - Soil \& Plant Science 62, 79-90.

Inal, A., Gunes, A., Zhang, F. and I. Cakmak (2007): Peanut/maize intercropping induced changes in rhizosphere and nutrient concentrations in shoots. Plant Physiology and Biochemistry 45, 350-356.

Jackson, M.L. (1958): Soil Chemical Analysis. PrenticeHall Inc., Englewood Cliffs, New Jersey.

Kübler, E., Aufhammer, W. and H.-P. Piepho (2008): Mixing effects in cereal-grain legume stands on the composition of the above ground dry matter yield and the grain yield in dependence of the mixing ratio. Die Bodenkultur 59, 85-94. 
Li, L., Tang, T., Rengel, Z. and F.S. Zhang (2004): Calcium, magnesium and microelement uptake as affected by phosphorus sources and interspecific root interactions between wheat and chickpea. Plant and Soil 261, 29-37.

Lošák, T., Hlušek, J., Martinec, J., Jandák, J., Szostkowa, M., Filipč́k, R., Maňásek, J., Prokeš, K., Peterka, J., Varga, L., Ducsay, L., Orosz, F. and A. Martensson (2011): Nitrogen fertilization does not affect micronutrient uptake in grain maize (Zea mays L.). Acta Agriculture Scandinavica, Section B - Soil \& Plant Science 61, 543-550.

Marschner, H. (1998): Role of root growth, arbuscular mycorrhiza, and root exudates for the efficiency in nutrient acquisition. Field Crop Research 56, 203-207.

Micek, P., Kulig, B., Woźnica, P. and A. Sajdak (2012): The nutritive value for ruminants of faba bean (Vicia faba) seeds and naked oat (Avena nuda) grain cultivated in an organic farming system. Journal of Animal and Feed Sciences 21, 773-786.

McCartney, D.H., Block, H.C., Dubeski, P.L. and A.J. Ohama (2006): Review: The composition and availability of straw and chaff from small grain cereals for beef cattle in western Canada. Canadian Journal of Animal Science 86, 443-455.

Mead, R. and W.R. Wiley (1980): The concept of land equivalent ratio and advantages in yields from intercropping. Experimental Agriculture 16, 217-228.

Mehlich, A. (1984): Mehlich 3 soil extractant: A modification of Mehlich 2 extractant. Communications in Soil Science and Plant Analysis 15, 1409-1416.

Midmore, D.J. (1993): Agronomic modification of resource use and intercrop productivity. Field Crops Research 34, 357-380.

Mondal, S., Samanta, C.C., Bairagi, B. and P. Biswas (2009): Effects of organic and inorganic forms of supplemental copper, zinc, iron and manganese at different dose levels on growth performance and plasma minerals in crossbred male calves. Animal Nutrition and Feed Technology 9, 45-50.

Neugschwandtner, R.W. and H.-P. Kaul (2016): Concentrations and uptake of macronutrients by oat and pea in intercrops in response to $\mathrm{N}$ fertilization and sowing ratio. Archives of Agronomy and Soil Science, DOI: 10.1080/03650340.2016.1147648.

Neugschwandtner, R.W. and H.-P. Kaul (2015): Nitrogen uptake, use and utilization efficiency by oat-pea intercrops. Field Crops Research 179, 113-119.
Neugschwandtner, R.W. and H.-P. Kaul (2014): Sowing ratio and $\mathrm{N}$ fertilization affect yield and yield components of oat and pea in intercrops. Field Crops Research 155, 159-163.

Neugschwandtner, R.W., Wagentristl, H. and H.-P. Kaul (2015a): Concentrations and uptake of macro and micronutrients by chickpea compared to pea, barley and oat in Central Europe. Journal of Cultivated Plants 67, 404-409.

Neugschwandtner, R.W., Wagentristl, H. and H.-P. Kaul (2015b): Nitrogen yield and nitrogen use of chickpea compared to pea, barley and oat in Central Europe. International Journal of Plant Production 9, 291-304.

Rengel, Z., Batten, G.D. and D.E. Crowley (1999): Agronomic approaches for improving the micronutrient density in edible portions of field crops. Field Crops Research 60, 29-40.

Schmidt, W. (2003): Iron solutions: Acquisition strategies and signaling pathways in plants. Trends in Plant Science 8, 188-193.

Sedlár, O., Balík, J., Černý, J., Peklová, L. and K. Kubešová (2014): Influence of nitrogen injection application on zinc and iron uptake by winter wheat and spring barley. Journal of Central European Agriculture 15, 39-48.

Shi, R., Zhang, Y., Chen, X., Sun, Q., Zhang, F., Römheld, V. and C. Zou (2010): Influence of long-term nitrogen fertilization on micronutrient density in grain of winter wheat (Triticum aestivum L.). Journal of Cereal Science 51, 165-170.

Tanaka, A. and S.A. Navasero (1966): Interaction between iron and manganese in the rice plant. Soil Science and Plant Nutrition 12, 29-33.

Vandermeer, J.H. (1989): The ecology of intercropping. Cambridge University Press, Cambridge, Great Britain.

Watson, C.A., Öborn, I., Edwards, A.C., Dahlin, A.S., Eriksson, J., Lindström, B.E.M., Linse, L., Owens, K., Topp, C.F.E. and R.L. Walker (2012): Using soil and plant properties and farm management practices to improve the micronutrient composition of food and feed. Journal of Geochemical Exploration 121, 15-24.

Yamamoto, S., Ito, K., Suzuki, K., Matsushima, Y., Watanabe, I., Watanabe, Y., Abiko, K., Kamada, T. and K. Sato (2014): Kinematic gait analysis and lactation performance in dairy cows fed a diet supplemented with zinc, manganese, copper and cobalt. Animal Science Journal 85, 330-335. 
Zając, T., Oleksy, A., Stokłosa, A., Klimek-Kopyra, A., Styrc, N., Mazurek, R. and W. Budzyński (2014): Pure sowings versus mixtures of winter cereal species as an effective option for fodder-grain production in temperate zone. Field Crops Research 166, 152-161.

Zerbini, E. and D. Thomas (2003): Opportunities for improvement of nutritive value in sorghum and pearl millet residues in South Asia through genetic enhancement. Field Crops Research 84, 3-15.

Zhang, F., Shen, J., Zhang, J., Zuo, Y., Li, L. and X. Chen (2010): Rhizosphere processes and management for improving nutrient use efficiency and crop productivity: Implications for China. Advances in Agronomy 107, 1-32.
Zuo, Y. and F. Zhang (2008): Effect of peanut mixed cropping with gramineous species on micronutrient concentrations and iron chlorosis of peanut plants grown in a calcareous soil. Plant and Soil 306, 23-36.

Zuo, Y. and F. Zhang (2009): Iron and zinc biofortification strategies in dicot plants by intercropping with gramineous species: A review. Agronomy for Sustainable Development 29, 63-71.

Zuo, Y., Zhang, F., Li, X. and Y. Cao (2000): Studies on the improvement in iron nutrition of peanut by intercropping with maize on a calcareous soil. Plant and Soil 220, $13-25$. 